\title{
High central venous oxygen saturation in the latter stages of septic shock is associated with increased mortality
}

\author{
Julien Textoris*, Louis Fouché, Sandrine Wiramus, François Antonini, Sowita Tho, Claude Martin and Marc Leone
}

See related commentary by Haase and Perner, http://ccforum.com/content/15/4/184

\begin{abstract}
Introduction: Current guidelines recommend maintaining central venous oxygen saturation $\left(\mathrm{S}_{\mathrm{cvO}}\right)$ higher than $70 \%$ in patients with severe sepsis and septic shock. As high levels of $\mathrm{ScvO}_{2}$ may reflect an inadequate use of oxygen, our aim was to evaluate the relation between maximal $\mathrm{ScvO}_{2}$ levels $\left(\mathrm{ScvO}_{2 \max }\right)$ and survival among intensive care unit (ICU) patients with septic shock.

Methods: We retrospectively analyzed data from all admissions to our ICU between January 2008 and December 2009. All septic shock patients in whom the $\mathrm{ScvO}_{2}$ was measured were included. The measures of $\mathrm{ScvO}_{2 \max }$ within the first 72 hours after the onset of shock were collected.

Results: A total of 1,976 patients were screened and 152 (7.7\%) patients met the inclusion criteria. The level of $\mathrm{ScvO}_{2 \max }$ was $85 \%$ (78 to 89 ) in the non-survivors, compared with $79 \%$ (72 to 87 ) in the survivors $(P=0.009$ ).

Conclusions: Our findings raise concerns about high levels of $\mathrm{S}_{\mathrm{CvO}}$ in patients with septic shock. This may reflect the severity of the shock with an impaired oxygen use. Future strategies may target an optimization of tissue perfusion in this specific subgroup of patients.
\end{abstract}

\section{Introduction}

Shock is characterized by either an inadequacy between tissue requirements in oxygen and oxygen delivery or the inadequate use of oxygen. The hemodynamic management of patients in shock aims at improving tissue oxygenation. Central venous blood saturation in oxygen $\left(\mathrm{ScvO}_{2}\right)$ is a useful tool reflecting the global transport and metabolism of oxygen. International guidelines suggest the need to optimize $\mathrm{ScvO}_{2}$ in the early phase of management of severe sepsis and septic shock [1].

Low levels reflect (i) an inadequate cardiac output with an excessive extraction of oxygen [2], (ii) a low hemoglobin concentration, and/or (iii) a low level of arterial oxygen pressure $\left(\mathrm{PaO}_{2}\right)$. In contrast, high levels of $\mathrm{ScvO}_{2}$ means either (i) a very high oxygen delivery in excess of tissue requirements and/or (ii) decreased cellular consumption

\footnotetext{
* Correspondence: julien.textoris@gmail.com Service d'anesthésie et de réanimation. Hôpital Nord, Assistance Publique Hôpitaux de Marseille, Université de la Méditerranée, Chemin des bourrely,
} 13915, Marseille Cedex 20, France

(C) 2011 Textoris et al.; licensee BioMed Central Ltd. This is an open access article distributed under the terms of the Creative Commons Attribution License (http://creativecommons.org/licenses/by/2.0), which permits unrestricted use, distribution, and reproduction in any medium, provided the original work is properly cited. of oxygen (mitochondrial dysfunction) and/or (iii) more rarely, a large arterio-venous shunt. In its most simple form, the oxyhemoglobin dissociation curve describes the relation between the partial pressure of oxygen ( $\mathrm{x}$ axis) and the oxygen saturation (y axis). Many factors influence the affinity of this binding, altering the curve shape. For example, acidosis and body hyperthermia induce a right shift of the curve. This shift promotes the release of oxygen to the tissues.

Because high levels of $\mathrm{ScvO}_{2}$ could reflect an impaired extraction of oxygen, our hypothesis was that $\mathrm{ScvO}_{2}$ levels above $80 \%$ in patients in septic shock hospitalized in ICU should be correlated with an increased mortality rate. The present study was aimed to correlate high levels of $\mathrm{ScvO}_{2}$ with mortality.

\section{Materials and methods}

Approval by the Ethics Committee and informed consent were waived due to the observational nature of the study. From January 2008 to December 2009, the charts

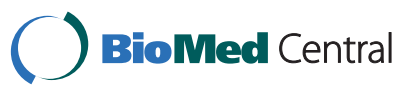


of all patients admitted to the ICU of our institution (Hôpital Nord, Marseilles, France) were retrospectively screened. We included patients aged $\geq 18$ yrs in septic shock, as defined elsewhere [3], and at least two available $\mathrm{ScvO}_{2}$ samples within the first 72 hours of shock. The patients with an ICU stay $<24$ hours were excluded.

The central venous catheter sampling site was in the superior vena cava. The position of the tip of the catheter was checked with chest radiography. Within the first 72 hours of shock, we collected the maximal $\mathrm{ScvO}_{2}\left(\mathrm{ScvO}_{2}\right.$ max $)$, and minimal $\mathrm{ScvO}_{2}\left(\mathrm{ScvO}_{2 \text { min }}\right)$ levels. The characteristics of patients were also collected, including: demographics (age, sex, body mass index (BMI), admission simplified acute physiology score (SAPS) II [4], and sequential organ failure assessment (SOFA) score (measured at the onset of shock)) [5]. Variables such as plasma lactate level, plasma creatinine level, daily urine output, ratio of arterial oxygen pressure related to inspired oxygen fraction $\left(\mathrm{PaO}_{2} / \mathrm{FiO}_{2}\right)$, hemoglobin, heart rate, mean arterial pressure, pulsatile saturation in oxygen $\left(\mathrm{SpO}_{2}\right)$ and body temperature were recorded contemporary to the $\mathrm{ScvO}_{2 \max }$ value. The patients were stratified according to their hospital mortality. The patients in septic shock were managed according to our local protocol in agreement with the Surviving Sepsis Campaign guidelines [1]. Briefly, fluid resuscitation was conducted according to dynamic indices of preload (pulse pressure variations and stroke volume variations) and echocardiography data analysis. Norepinephrine was used as the first line vasopressor in order to achieve a mean arterial pressure of $65 \mathrm{mmHg}$. As reported elsewhere, positive inotropes (dobutamine or isoproterenol) were introduced in the patients with low cardiac index and $\mathrm{ScvO}_{2}<70 \%[1,6]$. Renal replacement therapy was used only in patients exhibiting anuria or elevated potassium levels.

Statistical calculations were performed using the R project software (version 2.10). For continuous and ordinal variables, data were expressed as median with interquartile range. Comparisons between the two groups (survivors and non-survivors) were performed for epidemiological data and for hemodynamic data using a Mann-Whitney $U$ test. For dichotomous variables, percentages were computed. Comparisons of percentages were performed with the $\mathrm{Chi}^{2}$ test. We also performed a multivariate analysis by logistic regression to control for potential confounders in evaluating the relationship between $\mathrm{ScvO}_{2 \max }$ and outcome. Variables introduced into the model were those found to be significant in univariate analysis (with the exception of creatinine level, known to be linked to daily urine output, and SAPS II): body temperature, daily urine output, $\mathrm{ScvO}_{2 \text { max }}$, and plasma lactate. We checked the prediction models' residuals were distributed normally. All comparisons were two-tailed, and $P=0.05$ was required to exclude the null hypothesis.

\section{Results}

The screening of 1,976 charts identified 152 (7.7\%) patients in septic shock fulfilling the inclusion criteria (Figure 1). All the patients received sedation (Ramsay score between 3 and 5) and were ventilated. Norepinephrine was used in all patients. Thirty-four (22\%) patients were treated by positive inotrope. Ninety-one (60\%) patients were discharged from the hospital. At admission, the SAPS II score was significantly higher in the non-survivors than in the survivors (58 (38 to 72) vs. 44 (33 to 55); $P=0.01$ ). At the onset of septic shock, the SOFA score did not differ between the survivors and the non-survivors. The body temperature and the daily urine output were higher in the survivors than in the non-survivors $\left(38.1^{\circ} \mathrm{C}\right.$ (37.3 to 39$) v s 37.2^{\circ} \mathrm{C}(36.5$ to 38), $P=0.00004$, and $1,200 \mathrm{~mL} /$ day $(700$ to 1,600$) v s$ $685 \mathrm{~mL} /$ day (415 to 1,425), $P=0.006$, respectively). The plasma creatinine level and the plasma lactate level were lower in the survivors than in the non-survivors $(102$ $\mu \mathrm{mol} / \mathrm{L}$ (73 to 161$) v s 186 \mu \mathrm{mol} / \mathrm{L}$ (98 to 280 ), $P=$ 0.0002 , and $2.1 \mathrm{mmol} / \mathrm{L}$ (1.5 to 2.9$)$ vs $2.4 \mathrm{mmol} / \mathrm{L}$ (1.8 to 3.7 ), $P=0.05$, respectively) (Table 1 ).

The $\mathrm{ScvO}_{2 \max }$ was $83 \%$ (74 to $88 \%$ ) and the median $\mathrm{ScvO}_{2 \min }$ was $68 \%$ (62 to $73 \%$ ). Minimal $\mathrm{ScvO}_{2}$ was not different between the survivors and the non-survivors (Table 1). In contrast, the $\mathrm{ScvO}_{2 \max }$ was of $79 \%$ (72 to $87 \%$ ) in the survivors, as compared with $85 \%$ (78 to $89 \%$ ) in the non-survivors $(P=0.009)$ (Figure 2$)$. In these patients, only a high level of $\mathrm{ScvO}_{2 \text { max }}(\mathrm{OR}=1.06$; $\mathrm{CI}$ $95 \%=(1.01$ to 1.13$))$ and a lower body temperature $(\mathrm{OR}=0.48 ; \mathrm{CI} 95 \%=(0.32$ to 0.70$))$ were associated with hospital mortality. A contingency table with a cut-off of $\mathrm{ScvO}_{2 \max }$ at $80 \%$ is shown in Table 2. According to this cut-off, the rates of mortality were $30 \%\left(\mathrm{ScvO}_{2 \max }<80 \%\right)$ and $48 \%\left(\mathrm{ScvO}_{2 \max } \geq 80 \%\right)$, respectively $(P=0.04)$.

\section{Discussion}

In the present study, the $\mathrm{ScrO}_{2 \text { min }}$ cannot serve to discriminate the survivors and the non-survivors, and high $\mathrm{ScvO}_{2 \max }$ levels are associated with increased mortality. Thus, a dysoxia with an impaired extraction of oxygen may be suspected in septic shock patients.

The $\mathrm{ScvO}_{2 \min }$ was not associated with increased mortality. At first glance, this finding can be surprising. In the emergency department (ED), an early correction of $\mathrm{ScvO}_{2}$ was related to improved outcome [7]. In the ICU, the baseline values of $\mathrm{SvO}_{2}(69 \%$ [8]) seem to be higher than that observed in the ED (49\% [7]). Thus, although an aggressive resuscitation of the subgroup of patients with $\mathrm{ScvO}_{2}$ below $70 \%$ may be beneficial, these low levels 


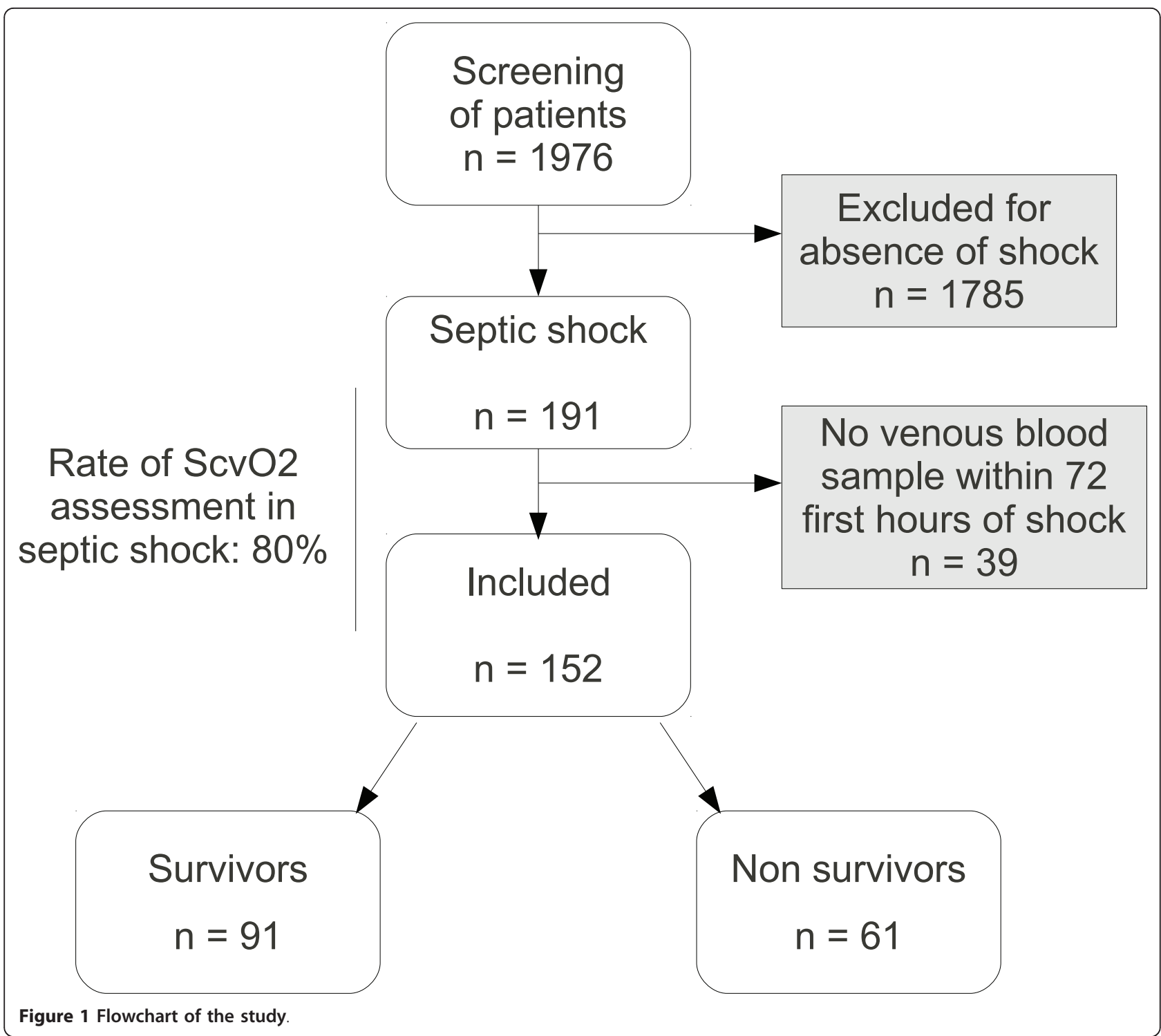

are less frequently observed in ICU patients than in ED patients. Low $\mathrm{ScvO}_{2}$ levels may be due to a combination of enhanced oxygen consumption, inadequately low cardiac index, low hemoglobin concentrations, and/or low arterial oxygen content. In the present study, all patients had endotracheal intubation and were ventilated. In addition, they were sedated by a combination of sufentanil and midazolam. Probably both of these treatments minimized the oxygen consumption [9]. In addition, the mean $\mathrm{SpO}_{2}$ was $96 \%$, and the mean level of hemoglobin at $9.5 \mathrm{~g} / \mathrm{dL}$. Thus, in the majority of our patients, a low level of $\mathrm{ScvO}_{2}$ may only reflect an inadequately low cardiac index [10]. This particular case is infrequent in adequately resuscitated septic shock patients [11].

One of the objectives of septic shock resuscitation is to raise the $\mathrm{ScvO}_{2}$ level above 70\%. Our study underlines that in patients with organ failure, high $\mathrm{ScvO}_{2}$ values may be a marker of unfavorable outcome. This result may not be generalizable to all septic patients. All our patients were sedated and mechanically ventilated. A previous study showed that $\mathrm{SvcO}_{2}$ increases significantly in response to intubation [9]. In addition, the $\mathrm{ScvO}_{2}$ values were obtained within the first 72 hours of ICU stay. This differs from a previous study, which was performed after the patient admission in the ED [7]. Future strategies should include subgroup stratification based on the $\mathrm{ScrO}_{2}$ levels. Such a model was suggested for patients admitted to the ED [12]. In this study, $\mathrm{ScvO}_{2}$ levels were stratified into three groups: hypoxia $\left(\mathrm{ScvO}_{2}<70 \%\right)$; normoxia $\left(\mathrm{ScvO}_{2} 71 \%\right.$ to $\left.89 \%\right)$; and hyperoxia $\left(\mathrm{ScvO}_{2} 90 \%\right.$ to $\left.100 \%\right)$. Using a multivariate analysis, the authors showed that hyperoxia was 
Table 1 Results of univariate analysis

\begin{tabular}{|c|c|c|c|c|}
\hline & All patients $n=152$ & Survivors $n=91$ & Non-survivors $n=61$ & $P$ \\
\hline Sex female & $51(34)$ & $31(34)$ & $20(33)$ & 0.99 \\
\hline Age (yrs) & 65 (53 to 74$)$ & 66 (52 to 74$)$ & $64(57$ to 75$)$ & 0.29 \\
\hline Body mass index & 24 (22 to 28$)$ & 24 (22 to 28$)$ & 24 (22 to 29) & 0.77 \\
\hline Body temperature $\left({ }^{\circ} \mathrm{C}\right)$ & $38.0(37.0$ to 38.5$)$ & 38.1 (37.3 to 39.0$)$ & $37.2(36.5$ to 38.1$)$ & $0.00004^{*}$ \\
\hline $\mathrm{ScvO}_{2 \min }(\%)$ & 68 (62 to 73$)$ & 69 (63 to 73$)$ & 68 (60 to 73$)$ & 0.61 \\
\hline $\mathrm{ScvO}_{2 \max }(\%)$ & 83 (74 to 88 ) & 79 (72 to 87 ) & 85 (78 to 89$)$ & $0.009^{*}$ \\
\hline Heart rate (beats/minute) & 105 (93 to 120$)$ & $104(92$ to 117$)$ & 108 (94 to 127$)$ & 0.21 \\
\hline Mean arterial pressure $(\mathrm{mmHg})$ & 71 (62 to 81) & 74 (63 to 77$)$ & 68 (61 to 81$)$ & 0.07 \\
\hline $\mathrm{SpO}_{2}(\%)$ & 96 (93 to 100$)$ & 96 (94 to 100$)$ & 96 (92 to 98 ) & 0.16 \\
\hline Glasgow Coma Scale & 15 (12 to 15$)$ & 15 (13 to 15$)$ & 13 (7 to 15$)$ & 0.09 \\
\hline Urine output (mL/day) & $1,100(600$ to 1,600$)$ & $1,200(700$ to 1,600$)$ & 685 (415 to 1,425$)$ & $0.006^{*}$ \\
\hline Creatinine $(\mu \mathrm{mol} / \mathrm{L})$ & 119 (78 to 204) & 102 (73 to 161$)$ & 186 (98 to 280 ) & $0.0002^{*}$ \\
\hline $\mathrm{PaO}_{2} / \mathrm{FiO}_{2}$ & 280 (123 to 365$)$ & 321 (128 to 380) & 184 (131 to 202) & 0.16 \\
\hline Hemoglobin $(g / d L)$ & $9.5(8.5$ to 11.0$)$ & 9.7 (8.5 to 10.9) & 9.4 (8.4 to 10.6) & 0.51 \\
\hline $\begin{array}{r}\mathrm{pH} \\
\text { Lactate }(\mathrm{mmol} / \mathrm{L})\end{array}$ & $\begin{array}{l}7.35(7.27 \text { to } 7.41) \\
2.1(1.6 \text { to } 3.4)\end{array}$ & $\begin{array}{l}7.37(7.32 \text { to } 7.41) \\
2.1(1.5 \text { to } 2.9)\end{array}$ & $\begin{array}{l}7.33(7.21 \text { to } 7.41) \\
2.4(1.8 \text { to } 3.7)\end{array}$ & $\begin{array}{l}0.11 \\
0.05^{*}\end{array}$ \\
\hline ICU stay (days) & 8 (4 to 19$)$ & 8 (4 to 18$)$ & 8 (4 to 20$)$ & 0.93 \\
\hline SAPS 2 & 47 (37 to 63) & 44 (33 to 55$)$ & 58 (38 to 72 ) & 0.01 \\
\hline SOFA & 7 (5 to 11$)$ & 7 (3 to 10$)$ & $8(5$ to 11$)$ & 0.40 \\
\hline
\end{tabular}

$\mathrm{ICU}$, intensive care unit; $\mathrm{PaO}_{2} / \mathrm{FiO}_{2}$ ratio, ratio of arterial oxygen pressure related to inspired oxygen fraction; SAPS, simplified acute physiologic score; SpO 2 , pulse oxymetry; $\mathrm{SvCO}_{2}$, central venous oxygen saturation; SOFA, Sequential Organ Failure Assessment score.

*variable included in the multivariate analysis. Results are expressed as number (percentage) or median (Interquartile range), as required.

associated with increased mortality. Similar results were reported after cardiac surgery [13].

This clinical finding supports the hypothesis of a decreased use of oxygen in sepsis [14]. An acquired defect in oxidative phosphorylation prevents cells from using molecular oxygen for adenosine triphosphate production and potentially causes sepsis-induced organ dysfunction. This misuse of oxygen, so-called cytopathic dysoxia, can result in high levels of $\mathrm{ScvO}_{2}$. In our study, we used an

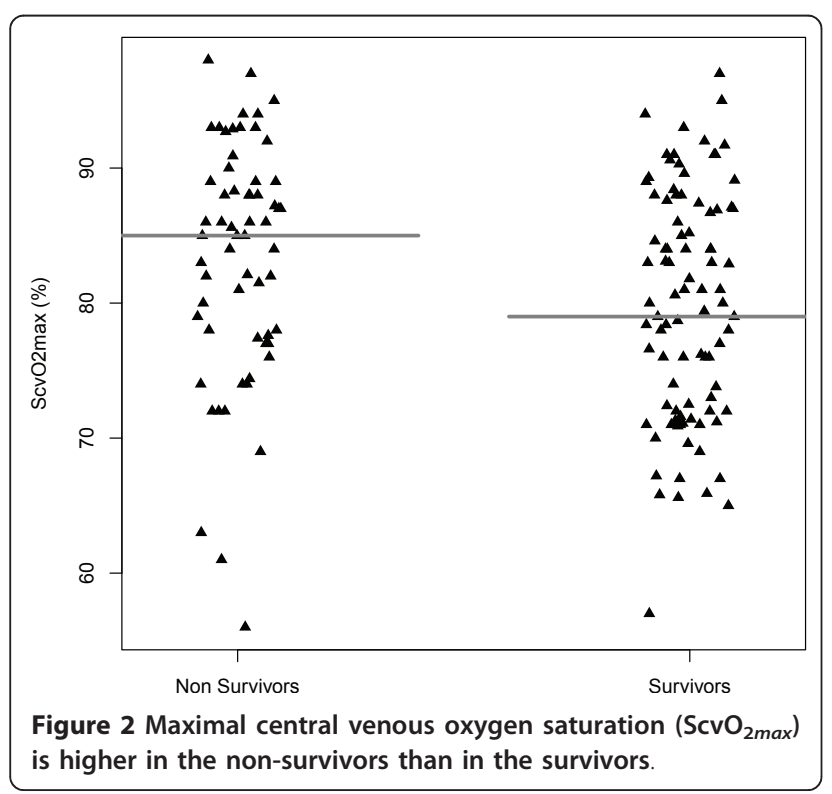

arbitrary cut-off at $80 \%$. The difference in mortality between the patients with $\mathrm{ScvO}_{2 \text { max }}$ value below or above $80 \%$ may generate clues regarding specific therapeutic strategies such as administering ubiquinone derivative targeted towards mitochondria in septic patients with dysoxia [15].

One may suspect microcirculatory impairments in patients with high $\mathrm{ScvO}_{2}$ levels. In line with this hypothesis, plasma lactate levels were higher in the non-survivors than in the survivors. Nevertheless, we did not find that $\mathrm{ScvO}_{2 \max }$ levels and plasma lactate levels were correlated (data not shown, assessed by a generalized linear model, $\left.P=0.62, r^{2}=0.14\right)$. The rise of plasma lactate level in shock is not only due to tissue hypoxia, but it can also be the consequence of the muscular aerobic $\mathrm{Na}^{+} / \mathrm{K}^{+} \mathrm{ATP}_{\text {ase }}$ driven production in response to an intense catecholaminergic stimulation [16]. This second mechanism may explain the absence of correlation. The microcirculation remains to be evaluated in septic patients with dysoxia. In a prior study, we showed that low tissue oxygen saturation $\left(\mathrm{StO}_{2}\right)$ was associated with increased mortality [17]. It would be interesting to investigate specifically the microcirculation of patients with high levels of $\mathrm{ScvO}_{2}$.

Table 2 Contingency table of mortality among a $\mathrm{ScvO}_{2 \text { max }}$ cut-off of $80 \%$

\begin{tabular}{rrrccc}
\hline & & Non survivors & Survivors & Mortality (\%) & P-value \\
\cline { 2 - 6 } $\mathrm{ScvO}_{2 \text { max }}$ & $<80 \%$ & 20 & 46 & 30 & 0.04 \\
& $\geq 80 \%$ & 41 & 45 & 48 & \\
\hline
\end{tabular}


The present study has several limitations. As this singlecenter study is retrospective, a selection bias might be possible. In our protocol, we did not measure $\mathrm{ScvO}_{2}$ continuously, thus we might have missed several events. We did not measure oxygen consumption, which may be important for the interpretation of this finding. Moreover, as we collected $\mathrm{ScvO}_{2}$ during the first 72 hours of resuscitation, $\mathrm{ScvO}_{2}$ measurements may reflect various states of the treatment. One can suggest that the arterial oxygen saturation may influence the $\mathrm{ScvO}_{2}$ levels. However, this variable did not differ between survivors and nonsurvivors. Another selection bias might be that patients with a low venous oxygen saturation are more likely to die in the first 48 hours after the onset of septic shock. However, in our study, only nine patients $(6 \%)$ died within this period. Their mean $\mathrm{ScvO}_{2 \text { min }}$ levels were $68 \%$. As we stated in the methods section, our protocol includes a preload assessment to guide fluid and global hemodynamic management of patients. At the bedside, the cardiac output was continuously monitored in more than $60 \%$ of our patients. Unfortunately, these data were not systematically reported in our patients' charts. More than $10 \%$ of data was lacking, therefore rendering the analysis difficult. Norepinephrine was used in all our patients to achieve a mean arterial pressure of $65 \mathrm{mmHg}$. The restoration of hemodynamics by using vasopressors may cause venous hyperoxia, by increasing cardiac output. As the use of high doses of vasopressors has been associated with increased mortality [18], this may be another potential confounding factor.

\section{Conclusions}

In conclusion, high levels of $\mathrm{ScvO}_{2}$ in septic shock patients may be associated with increased mortality. Future studies relating outcome and $\mathrm{ScvO}_{2}$ should stratify the patients according to venous hypoxia, normoxia and hyperoxia levels.

\section{Key messages}

- High levels of $\mathrm{ScvO}_{2}$ (> 80\%) during the first 72 hours of resuscitation of septic shock patients is associated with increased mortality

- High levels of $\mathrm{ScvO}_{2}$ could reflect an impaired use of oxygen

\footnotetext{
Abbreviations

BMI: Body Mass Index; ED: emergency department; $\mathrm{FiO}_{2}$ : inspired fraction in oxygen; Cl: confidence interval; ICU: intensive care unit; OR: odds ratio; $\mathrm{PaO}_{2}$ : arterial pressure of oxygen; SAPS II: Simplified Acute Physiology Score I; $\mathrm{SCVO}_{2}$ : central venous oxygen saturation; SOFA: Sequential Organ Failure Assessment; $\mathrm{SpO}_{2}$ : pulsatile oxygen saturation; $\mathrm{StO}_{2}$ : tissular oxygen saturation.
}

\section{Authors' contributions}

All the authors contributed to the elaboration of this manuscript. LF and ST performed data extraction and wrote the manuscript draft. JT and SW performed data management and wrote the manuscript. FA performed data management and statistical analysis, while CM and ML did the study conception and wrote the manuscript. All authors read and approved the final version of the manuscript.

\section{Competing interests}

The authors declare that they have no competing interests.

Received: 3 January 2011 Revised: 27 May 2011 Accepted: 26 July 2011 Published: 26 July 2011

\section{References}

1. Dellinger RP, Levy MM, Carlet JM, Bion J, Parker MM, Jaeschke R, Reinhart K, Angus DC, Brun-Buisson C, Beale R, Calandra T, Dhainaut J, Gerlach H, Harvey M, Marini JJ, Marshall J, Ranieri M, Ramsay G, Sevransky J, Thompson BT, Townsend S, Vender JS, Zimmerman JL, Vincent J: Surviving Sepsis Campaign: international guidelines for management of severe sepsis and septic shock: 2008. Crit Care Med 2008, 36:296-327.

2. Marx G, Reinhart K: Venous oximetry. Curr Opin Crit Care 2006, 12:263-268.

3. Calandra T, Cohen J: The international sepsis forum consensus conference on definitions of infection in the intensive care unit. Crit Care Med 2005, 33:1538-1548.

4. Le Gall JR, Lemeshow S, Saulnier F: A new Simplified Acute Physiology Score (SAPS II) based on a European/North American multicenter study. JAMA 1993, 270:2957-2963.

5. Vincent JL, Moreno R, Takala J, Willatts S, De Mendonça A, Bruining H, Reinhart CK, Suter PM, Thijs LG: The SOFA (Sepsis-related Organ Failure Assessment) score to describe organ dysfunction/failure. On behalf of the Working Group on Sepsis-Related Problems of the European Society of Intensive Care Medicine. Intensive Care Med 1996, 22:707-710.

6. Leone M, Boyadjiev I, Boulos E, Antonini F, Visintini P, Albanèse J, Martin C: A reappraisal of isoproterenol in goal-directed therapy of septic shock. Shock 2006, 26:353-357.

7. Rivers E, Nguyen B, Havstad S, Ressler J, Muzzin A, Knoblich B, Peterson E, Tomlanovich M: Early goal-directed therapy in the treatment of severe sepsis and septic shock. N Engl J Med 2001, 345:1368-1377.

8. Gattinoni L, Brazzi L, Pelosi P, Latini R, Tognoni G, Pesenti A, Fumagalli R: A trial of goal-oriented hemodynamic therapy in critically ill patients. SvO2 Collaborative Group. N Engl J Med 1995, 333:1025-1032.

9. Hernandez G, Peña H, Cornejo R, Rovegno M, Retamal J, Navarro JL, Aranguiz I, Castro R, Bruhn A: Impact of emergency intubation on central venous oxygen saturation in critically ill patients: a multicenter observational study. Crit Care 2009, 13:R63.

10. Perner A, Haase N, Wiis J, White JO, Delaney A: Central venous oxygen saturation for the diagnosis of low cardiac output in septic shock patients. Acta Anaesthesio/ Scand 2010, 54:98-102.

11. van Beest PA, Hofstra JJ, Schultz MJ, Boerma EC, Spronk PE, Kuiper MA: The incidence of low venous oxygen saturation on admission to the intensive care unit: a multi-center observational study in The Netherlands. Crit Care 2008, 12:R33.

12. Pope JV, Jones AE, Gaieski DF, Arnold RC, Trzeciak S, Shapiro NI: Multicenter study of central venous oxygen saturation $(\operatorname{ScvO}(2))$ as a predictor of mortality in patients with sepsis. Ann Emerg Med 2010, 55:40-46.

13. Perz S, Uhlig T, Kohl M, Bredle DL, Reinhart K, Bauer M, Kortgen A: Low and "supranormal" central venous oxygen saturation and markers of tissue hypoxia in cardiac surgery patients: a prospective observational study. Intensive Care Med 2011, 37:52-59.

14. Levy RJ: Mitochondrial dysfunction, bioenergetic impairment, and metabolic down-regulation in sepsis. Shock 2007, 28:24-28.

15. Lowes DA, Thottakam BMV, Webster NR, Murphy MP, Galley HF: The mitochondria-targeted antioxidant MitoQ protects against organ damage in a lipopolysaccharide-peptidoglycan model of sepsis. Free Radic Biol Med 2008, 45:1559-1565.

16. Levy B, Gibot S, Franck P, Cravoisy A, Bollaert P: Relation between muscle $\mathrm{Na}+\mathrm{K}+$ ATPase activity and raised lactate concentrations in septic shock: a prospective study. Lancet 2005, 365:871-875.

17. Leone M, Blidi S, Antonini F, Meyssignac B, Bordon S, Garcin F, Charvet A, Blasco V, Albanèse J, Martin C: Oxygen tissue saturation is lower in nonsurvivors than in survivors after early resuscitation of septic shock. Anesthesiology 2009, 111:366-371. 
18. Levy MM, Macias WL, Vincent JL, Russell JA, Silva E, Trzaskoma B,

Williams MD: Early changes in organ function predict eventual survival in severe sepsis. Crit Care Med 2005, 33:2194-2201.

doi:10.1186/cc10325

Cite this article as: Textoris et al:: High central venous oxygen saturation

in the latter stages of septic shock is associated with increased

mortality. Critical Care 2011 15:R176.

Submit your next manuscript to BioMed Central and take full advantage of:

- Convenient online submission

- Thorough peer review

- No space constraints or color figure charges

- Immediate publication on acceptance

- Inclusion in PubMed, CAS, Scopus and Google Scholar

- Research which is freely available for redistribution

Submit your manuscript at 